\title{
Blending Theoretical and Practical Experiences for a Multimedia Development Graduate Course
}

\author{
Fauzy Wan \\ Universiti Sains Malaysia, Penang, Malaysia
}

fauzy@usm.my

Abstract

The Center of Instructional Technology and Multimedia at the Universiti Sains Malaysia (Science University of Malaysia) has for the past three years conducted a Multimedia Development course for the Masters of Education program. This paper will present experiences and opinions from both the instructor's and students' of the course. The course objective is to provide both theoretical and practical experiences in Multimedia Courseware development to be used in the classroom or training facilities. Students are required to submit a four-research article revie w as well as produce two-multimedia courseware as their practical component for the course. They are also required to undertake a final examination. From the evaluation and assessment of the course the students are very positive in the experiences that the $y$ have undergone and their major complaint is a lack of time to complete the practical component of the course. The instructor utilized PowerPoint and Microsoft Publisher as the introductory software for Multimedia and Web Page development.

Keywords: Multimedia Courseware Development, Web Page Development, Theory and Practice, Authoring

\section{Introduction}

As Information Communication Technologies (ICT) are becoming popular and often integrated into the school learning environment, considerations for both hardware and software requirements have to be seriously considered. This is to ensure that a high level of quality is maintained in the utilization of these two components of ICT. In the MSc. Ed. program this course is only offered after the students have undergone courses in basic educational research, alternative views of instructional and learning theories. The aim of this Multimedia Development graduate course is to ensure that teachers are both familiar and comfortable utilizing these technologies. Students participating in this course are certified full time teachers with at least 5 years of teaching experience. The subjects taught by these teachers' range from the arts, social sciences to the pure sciences. The objective of this course is to emphasize the theoretical framework and guidelines as well as the practical experiences of actual multimedia courseware development. As in any multimedia development, a developer may get carried away with the utilization of various multimedia elements as compared to its effective use. The old adage of "Should as opposed to Could" was regularly reminded to these students. This approach was undertaken to ensure that any

Material published as part of these proceedings, either on-line or in print, is copyrighted by Informing Science. Permission to make digital or paper copy of part or all of these works for personal or classroom use is granted without fee provided that the copies are not made or distributed for profit or commercial advantage AND that copies 1) bear this notice in full and 2) give the full citation on the first page. It is permissible to abstract these works so long as credit is given. To copy in all other cases or to republish or to post on a server or to redistribute to lists requires specific permission from the publisher at Publisher@InformingScience.org courseware development adhere to the prescribed instructional design framework and models. This in turn ensured that the courseware produced are of high quality, relevant, carefully planned and based on sound theoretical theories. 


\section{Student Background}

The latest group of students (2002) undertaking this course was 26 students. These students are full time teachers undertaking this course as a part time student in the Master of Education program at the School of Educational studies, Universiti Sains Malaysia. The subject matter taught by these teachers ranged from the primary school level till year 12 (K through 12 ). The main subjects taught are usually standard topics taught in school involving language, social sciences the pure sciences and mathematics but information communication technologies (ICT) topics are generally the minor topic taught by all these teachers at their respective schools. On the average these teachers have more than 7 years experience in teaching. These teachers are also regarded as the ICT resource person at their respective schools with a majority of them responsible for the computer facilities on the school premises.

\section{Course Background}

The course is titled "Multimedia in Education". It is a14 week graduate level course involving both the theoretical and practical aspects of multimedia development. The course is conducted by a weekly twohour lecture involving the theoretical component with another two-hour tutorial for a practical "hands on" experience. The evaluation for the course is carried on two components, a coursework requirement and a final examination at the end of the semester. The main topics for this course are:

a) Theories and principles of learning

b) Instructional design and the development of educational multimedia materials

c) Multimedia concepts and principles as well as the integration of these concepts in teaching and learning

d) Principles and steps involved with the development and authoring of interactive multimedia materials. Topics include story boarding, flow charts, information mapping as well a formative evaluation

e) Procedural principles in the development of multimedia elements: graphics, video, audio, animation and texts with popular current software.

f) Utilizing PowerPoint as an integrated presentation software for multimedia courseware

g) Web site design and development with Microsoft Publisher

\section{Course Evaluation}

Students undertaking this course are evaluated by their performance of the coursework component that carries a value of 60 percent as well as a final examination, which is 40 percent. The coursework is further divided into:

a) Four research article reviews- $20 \%$

b) One Interactive PowerPoint Presentation- $15 \%$

c) An educational Web Site- $25 \%$

The duration between each project required date of submission is 3 weeks. The final examination required students to answer four from the six essay questions provided. The questions covered topics involving in depth analysis of Learning/Instructional theories, practical applications of electronic presentations as well as web site development models as applied to educational and instructional scenarios.

Questions involving the historical evolution of Multimedia and its application towards education as presented by documented research studies are also presented to the students. 


\section{Instructor's Experience}

This is the third years since this course was first introduced into the Master in Education program at the School of Educational Studies in Universiti Sains Malaysia. The course is conducted at the Center of Instructional Technology and Multimedia at the same university. The most recent offering for this course was from June 2002 till the middle of September 2002. The course has undergone minor changes from when it was first offered in 2000. These changes involved the selection of multimedia editing software as well as software for the development of an electronic presentation as well as the primary software for the creation of a Web site. The course begins with a background and expectation survey to be filled by the students on the first day of class. The questions are:

a) Name

b) Background and ICT experiences

c) Have you develop a Multimedia package; if yes please provide a brief explain.

d) E-Mail account (have used, always use, have account but not active, no account)

e) Please explain current computer configuration owned or have accessed to.

f) Please explain comfort level utilizing Multimedia editing software, please list name of software you are familiar with.

g) Please explain why taking the course.

h) Please explain expectations from the course.

The survey forms are then collected and analyzed for an overall impression of the students undertaking the course. Since the use of emails is just getting to be widespread in Malaysia, many of the students either have account but not actively using them while a small majority does not posses an electronic email account. This course required that all students activate an email account and all email addresses are collected and then distributed throughout the class.

The goal of the email information was to provide an avenue for communications, discussions as well as collaborations between the students as the course progress through the semester. The email also provided a means to broadcast important information concerning the course regularly by the instructor.

The hidden agenda was to promote the thinking of utilizing the internet as well as raising the comfort level of finding and sharing information found on the internet especially concerning research articles as well as "unconscious" evaluation of web sites visited.

At the end of the semester it can be noted that students were very comfortable to discuss things via email and exchanging information. The phrase "attach the file to my email" was often heard together with "download" as well as "I got this from this website". At the end of the semester a course evaluation was carried out and the "comment" section was always filled with comments reflecting a raised comfort level in using multimedia as well as utilizing the Internet as an information resource as compared to the beginning of the semester. The students were also more critical to the quality of multimedia courseware commercially produced as well as web sites visited.

\section{Theoretical Component}

The students are introduced to the various definitions of multimedia as well as the various applications towards education. The main approaches of utilizing multimedia were emphasized from the perspectives utilizing multimedia as a courseware, information resource or a curriculum program in education. They were then required to find four articles as to the varied application of multimedia for education limited 
only to research articles from 1995 till the present. Students were required to report on the advantages, disadvantages of the multimedia applications and as a conclusion of the report, the students are to add their opinions as to whether they agreed or disagreed to the article and explain their opinions. Students were allowed to report on similar or identical articles, the main emphasis were their opinion and recommendations.

Instructional design (ID) (Seels \& Glassgow, 1998) approaches such as the generic A.D.D.I.E (Analyze, Design, Develop, Implement, Evaluate) ID model was emphasized. Various Instructional System Design (ISD) models involving Cagne' Briggs and Wager, Riser \& Dick, Dick \& Carrey and Seels \& Glasgow ISD model II were also introduced, compared and discussed. Learning theories covering from the beha viorist, cognitive and constructivist viewpoints were also presented to the students together with Multimedia courseware development models and methodologies as recommended by Alessi \& Trollip (2001). Proper instructional design was stressed as well as multimedia courseware design (Boyle, 1997). Approaches concerning Web page design and development utilized principles recommended by Driscoll, (1998), Coorough, (2001) with the collection of research papers edited by Khan, (1997).

\section{Practical Component}

The students are first exposed to examples of graphic editing software such as Paint Shop Pro, Adobe Photo Shop as well as several shareware software available at WWW.Download.com. Concepts concerning masking, duplicating and special effects filtering are introduced with ready- made images. The process of finding and downloading image files from the Internet are also introduced. The process of scanning printed materials as well as three-dimensional objects are also demonstrated to the students for the first hour of the tutorial. The second hour is then available to the students to experiment scanning or downloading images. Legal issues as well as copyright issues are emphasized to ensure that any image utilized by the students for inclusion into their multimedia package are in accordance of the rules concerning fair and not violating any laws governing the image use. The next tutorial involves capturing video and audio clips for editing purposes utilizing digital still and digital video cameras. Recording audio material from various sources such as audiocassettes, live recording, audio CDs as well as capturing only the audio component of a video movie. As most multimedia elements require a large amount of storage and editing memory space, dealing with storage issues in different media formats are also discussed as well as demonstrated. The most popular medium found to be practical are in the form of Compact Disc Record able media (CD-R) and CD-Rewritable (CD-RW) media for both the audio and visual component of their project.

Subsequent tutorials involved utilizing relevant authoring software for the development of PowerPoint presentations as well as web page development. Since this is the third offering of this course, there are several sets of both excellent and poor examples of the multimedia projects developed by past students. The challenges faced by the students were ways to create multimedia projects that reflected both innovations and creativity without duplicating past ideas or errors.

\section{Conclusion}

At the middle of the semester the students are required to present their final PowerPoint package. The final PowerPoint package embedded the various instructional theories and models especially Cagne'Briggs model of instruction (Reigeluth, 1983). The multimedia software produced included interactive elements such as hyper linking, hypermedia control, learner control, information structuring, an evaluation component as well as a user information map to help users from being "lost" in hyper space as well as getting cognitive overload. As for the Web Site component, the results were also similar and students were very proud of their achievements. Their web sites were also hosted on public domain hosting sites such as Yahoo and Geocities. 
As a direct result of their achievements a majority of the students from the class reported that the School administration has assigned them to create and maintain their respective school web sites.

The blending approach of theoretical and practical knowledge in the development of multimedia materials for instruction and learning have been successful in producing higher quality instructional materials. Students were more confident with their creativity and manipulation of multimedia elements as reflected by the high educational quality of the packages that they produced.

\section{References}

Alessi, S. M. \& Trollip, S. R. (2001) Multimedia for learning: methods and development,(3rd ed.) Massachusetts,. Allyn \& Bacon

Boyle, T. (1997). Design For Multimedia Learning. Herfordshire. Prentice Hall Europe.

Coorough, C. (2001). Multimedia and the web: Creating digital excitement, Florida, Hardcourt College Publishers

Driscoll, M. (1998). Web-Base training: Using technology to design adult learning experiences. San Francisco, JossseyBass/Pfeiffer

Khan, B. H. (Ed.) (1997). Web-Based instruction. New Jersey, Educational Technology Publications

Reigeluth, C. M. (Ed.) (1983). Instructional-Design theories and models: An overview of their current status. New Jersey, Educational Technology Publications

Seels, B. \& Glassgow, Z. (1998). Making Instructional Decisions ( $2^{\text {nd }}$ ed.) Columbus, Ohio. Prentice Hall.

\section{Biography}

Fauzy Wan has been a lecturer at the Center of Instructional Technology and Multimedia for the past 20 years. He began by teaching topics concerning Educational Technology and evolving to Instructional Technology. His first involvement with Multimedia were topics ranging from Video production, Synchronize Slide-tape programs, programming in BASIC and now utilizing various authoring packages for the development of Instructional Multimedia program. He is currently an Associate professor and involved directly with several national and international projects involving the Integration Computer Technology in Education. His current research areas involve Instructional Design, Multimedia Development and Mobile Learning. 